\title{
Determination of heavy metal ions in extracts of the prickly root of eleutherococcus
}

\author{
C Alsu S. Ibragimova, ${ }^{1}$ Alla Yu Krynitskaya,${ }^{2}{ }^{+}$Elena V. Petukhova, ${ }^{3}$ and Pavel P. Sukhanov ${ }^{4}$ \\ ${ }^{1}$ Department of Food Biotechnology. ${ }^{2}$ Department of Food Biotechnology. ${ }^{3}$ Department of Food \\ Biotechnology. ${ }^{4}$ Department of Food Biotechnology Processes and Apparatus. Kazan National Research \\ Technological University. K. Marx St., 68. Kazan, 420015. Tatarstan Republic. Russia. \\ Phone: ${ }^{1)}$ (843) 231-89-13; ${ }^{4)}$ (843) 231-95-13.E-mail: ${ }^{1)}$ alsu.alsu-ibragimova2017@yandex.ru; \\ 2)paulalla@yandex.ru; ${ }^{3)}$ petel07@yandex.ru; ${ }^{4)}$ paulpost3@yandex.ru
}

\begin{abstract}
*Supervising author; ${ }^{+}$Corresponding author
Keywords: heavy metals, stripping voltammetry, water, plant extracts.
\end{abstract}

\section{Abstract}

The content of cadmium, mercury, zinc and cuprum ions in extracts of Eleutherococcus prickly root powder was determined by stripping voltammetry. The content of $\mathrm{Zn}^{2+}$ cations in the aqueous extracts of the plant adaptogen was below the detection limit for the analysis method used. The concentration of ions $\mathrm{Cd}^{2+}$, $\mathrm{Pb}^{2+}$ in aqueous extracts it was less than $0.0002 \mathrm{mg} / \mathrm{kg}$. The amount of cuprum ions did not exceed $2.6 \mathrm{mg} / \mathrm{kg}$. Consequently, the concentrations of heavy metal cations are below the MPC level (maximum permissible concentration), which allows us to speak about the toxicological safety of the plant material studied. Increasing the maceration temperature from 23 to $40{ }^{\circ} \mathrm{C}$ reduces the efficiency of the process. The possible causes of this phenomenon are discussed. The source of raw materials does not have a significant effect on the content of pollutants. For the extraction of plant materials, along with distilled water, tap water can be used, which in its performance meets the standards for the content of heavy metal ions in all areas of the city of Kazan. The maximum value of the total pollution indicator is $4.5 \mathrm{mg} / \mathrm{l}$. It was found in tap water selected in the Vakhitovsky district of the city of Kazan. However the maximum lead content is characteristic of the water selected in the Soviet district of the city. Distillation of water is expected to reduce pollution by pollutants. However complete purification from heavy metal ions does not occur. The most intense distillation is the purification of water from cuprum ions. The minimum amount of pollutants is found in ethanolic extracts of Eleutherococcus root powder. It is obvious that ethanol, as an extractant of heavy metal cations, is less preferable than water.

\section{References}

[1] A.Yu. Krynitskaya, A.S. Ibragimova. The use of Eleutherococcus powder in the production of a functional bakery product. Cooperative movement in the system of rural development: Collection of scientific papers of the scientific-practical conference. Kazan: "Printing-service of the XXI century» Publishing House. 2018. P.249-251. (russian)

[2] A.S. Saveleva, A.Yu. Krynitskaya, and A.S. Ibragimova. The influence of the additive of spelt flour on the processes of fermentation of wheat dough. Butlerov Communications. 2018. Vol.55. No.9. P.43-47. DOI: 10.37952/ROI-jbc-01/18-55-9-43

[3] V.I. Kocherov, A.N. Kozitsina, A.V. Ivanova, T.S. Mitrofanova, A.I. Matern. Stripping voltammetry: a learning and teaching aid for the course "Analytical Chemistry and Physical and Chemical Methods of Analysis". Ekaterinburg: UrFU. 2010. 110p. (russian)

[4] A.V. Fetisov, G.A. Kozhina, A.N. Ermakov, V.B. Fetisov, K.Yu. Shunyaev, A.B. Shubin, S.A. Petrova, ${ }^{3}$ and R.G. Zakharov. Effect of mechanical activation on the electrochemical characteristics of manganese oxides $\mathrm{Mn}_{\mathrm{m}} \mathrm{O}_{\mathrm{m}+1}(\mathrm{~m}=1,2,3)$. Butlerov Communications. 2012. Vol.32. No.13. P.43-54. ROI: jbc-02/1232-13-43

[5] A.V. Kolesnikov. Investigation of the effect of surfactant in the inversion-voltammetric method analysis of metals. Butlerov Communications. 2016. Vol.47. No.7. P.93-96. DOI: 10.37952/ROI-jbc-01/16-47-7-93

[6] R.A. Zilberg, Yu.A. Yarkaeva, D.I. Dubrovsky, A.I. Khabletdinova, and V.N. Maistrenko. Voltammetric "electronic tongue" for recognition of methionine-containing pharmaceuticals. Butlerov Communications. 2018. Vol.56. No.11. P.32-37. DOI: 10.37952/ROI-jbc-01/18-56-11-32

[7] Guideline 31-03/04. Quantitative chemical analysis of samples of natural, drinking and waste waters. Methods for measuring mass concentrations of zinc, cadmium, lead and cuprum by stripping 
DETERMINATION OF HEAVY METAL IONS IN EXTRACTS OF THE PRICKLY ROOT OF ELEUTHEROCOCCUS 66-71 voltammetry using TA analyzers. HDPE F 14.1: 2: 4.222-06. Tomsk: Center for Risography and Copying PE Tislenko. 2011. 24p. (russian)

[8] G.Yu. Samoylenko, E.A. Bondarevich, N.N. Kotsyurzhinskaya. Studying the quantitative indices of heavy metals in soils and wild-growing plants by an inversion-voltamperometric method. Ecology. Chita 2017. P.34. (russian)

[9] Hygienic requirements for water from centralized water supply systems: SanPiN 2.1.4.1074-01. Drinking water. Hygienic requirements for water quality of centralized drinking water supply systems. Quality control. Hygienic requirements for ensuring the safety of hot water systems. Moscow. 2001. No.24. P.30. (russian)

[10] N.A. Razumnikov, V.I. Talantsev, I.N. Razumnikov. Regularities of spiny eleuterococcus leaves biomass accumulation and trace substances content in it. Forest. Ecology. Nature use. Bulletin of MarSTU. 2012. No.1. P.87-93. (russian)

[11] N.A. Razumnikov. The content of eleutheroside and trace elements in rhizomes and roots of Eleutherococcus prickly. Agronomy. 2011. No.2. P.52-55. (russian) 